\title{
Evaluation of microleakage in human, bovine and swine enamels
}

\section{Avaliação da infiltração marginal em esmalte humano, bovino e suíno}

\author{
Allan Abuabara* \\ Alex José Souza dos Santos** \\ Flavio Henrique Baggio Aguiar** \\ José Roberto Lovadino***
}

\begin{abstract}
The suitability of bovine and swine teeth has been evaluated when they are used as substitutes for extracted human teeth in varied researches. This study evaluated in vitro the marginal microleakage in human, bovine and swine enamel. Cubic cavities $\left(2 \times 2 \times 2 \mathrm{~mm}^{3}\right)$ were prepared in enamel blocks from human, swine and bovine teeth. The cavities were filled with composite resin and conventional glass-ionomer cement. All the samples were thermocycled for 1,000 cycles $\left(5 \pm 2^{\circ} \mathrm{C}-55 \pm 2^{\circ} \mathrm{C}\right)$ and immersed in $2 \%$ methylene blue solution for 12 hours. The microleakage was quantified by a spectrophotometric technique. The results were statistically analyzed using ANOVA and Tukey's test. The glass-ionomer cement presented significantly higher leakage means $(\mu \mathrm{g} / \mathrm{ml} \pm \mathrm{SD})$ than the composite resin for all substrates $(0.0695 \pm 0.01313 v$ s. $0.0471 \pm 0.0163, \mathrm{p}<0.01)$. No significant differences were found between bovine and swine enamel (0.0668 $\pm 0.0246 v$ s. $0.0674 \pm 0.0286)$; however, both presented statistically higher leakage means than human enamel $(0.0407 \pm 0.0195, p<0.01)$. It was concluded that the microleakage pattern was affected by substrates, and that bovine and swine substrates allow higher marginal leakage than human substrates. The results indicate there should be precaution in the substitution of human substrate in laboratory studies of microleakage.
\end{abstract}

DESCRIPTORS: Dental enamel; Glass ionomer cements; Composite resins.

RESUMO: A adequação de dentes bovinos e suínos na substituição de dentes humanos extraídos tem sido avaliada em vários estudos. O objetivo deste estudo in vitro foi analisar o padrão de infiltração marginal em esmaltes humano, bovino e suíno. Cavidades cúbicas $\left(2 \times 2 \times 2 \mathrm{~mm}^{3}\right)$ foram realizadas em blocos de esmalte obtidos de dentes molares humanos, incisivos bovinos e molares suínos. As cavidades foram restauradas com compósito resinoso fotopolimerizável e cimento de ionômero de vidro. Os espécimes foram submetidos à termociclagem por 1.000 ciclos entre $5 \pm 2{ }^{\circ} \mathrm{C}$ e $55 \pm 2{ }^{\circ} \mathrm{C}$ e imersos em azul de metileno a $2 \%$, por 12 horas. A concentração de corante infiltrado foi medida, quantitativamente, através de espectrofotometria. Os dados foram transformados em $\mu \mathrm{g} / \mathrm{ml} \mathrm{e} \mathrm{subme-}$ tidos à análise estatística ANOVA, seguida pelo teste de Tukey. As médias de infiltração marginal $(\mu \mathrm{g} / \mathrm{ml} \pm \mathrm{DP})$ nos esmaltes bovino e suíno não foram significativamente diferentes $(0,0668 \pm 0,0246 v s$. 0,0674 $\pm 0,0286)$, mas foram superiores e estatisticamente diferentes $(p<0,01)$ das encontradas no esmalte humano $(0,0407 \pm 0,0195$, $\mathrm{p}<0,01$ ), e as médias de infiltração marginal foram superiores nas restaurações realizadas com o cimento de iônomero de vidro $(0,0695 \pm 0,01313$ vs. 0,0471 $\pm 0,0163, \mathrm{p}<0,01)$. Os resultados permitiram concluir que os substratos bovino e suíno permitem uma maior infiltração marginal que o esmalte humano, indicando que a capacidade de selamento marginal pode ser afetada por diferenças entre esses substratos. Os resultados indicam que se deve ter prudência na substituição do esmalte humano em estudos laboratoriais de microinfiltração.

DESCRITORES: Esmalte dentário; Cimentos de ionômeros de vidro; Resinas compostas.

\section{INTRODUCTION}

Non-carious extracted human teeth are becoming difficult to obtain due to the progress in conservative dental treatments. Two substrates have been reported in literature for laboratory studies: human and bovine teeth. Bovine teeth, because of their availability as well as their larger size, have been used as substitutes for human substrate. The teeth of all mammals appear to be very similar on a histochemical and anatomic ba$\operatorname{sis}^{12,26,29}$. However, different statements were found in the related literature about the applicability of bovine and other substrates.

The number and diameter of dentinal tubules in teeth of experimental animals used in dental

\footnotetext{
*DDS; **PhD; ***PhD, Chairperson - Department of Restorative Dentistry, School of Dentistry of Piracicaba, State University of Campinas.
} 
Abuabara A, Santos AJS, Aguiar FHB, Lovadino JR. Evaluation of microleakage in human, bovine and swine enamels. Braz Oral Res 2004;18(4):312-6.

research, such as the rat, cat, dog, and monkey, have been examined ${ }^{9}$ and they showed similarity to those in human teeth. Tagami et al. ${ }^{27}$ (1989) reported that the permeability of coronal bovine incisor dentin is six to eight times less than that of unerupted coronal human third molar dentin but similar to that of human root dentin. Nakamichi et al. $^{16}$ (1983) evaluated bovine teeth as possible substitutes for human teeth in adhesion tests. The use of bovine teeth in dental research is largely due to their study, which reported similar resin bond strengths for enamel and superficial dentin of bovine and human teeth. However, they also examined the morphological differences between bovine and human enamel and dentin. Unetched bovine enamel appeared slightly rougher. A different acid etching pattern was noted between the arcade-shaped human enamel and the small ovalshaped bovine enamel.

Microleakage is a major focus of researches, which strive to improve the longevity of composite restorations ${ }^{25}$. Even so, the current literature is insufficient to compare various substrates with human and bovine ones in microleakage tests. Most of the comparisons are made with adhesion tests and verifying the dentin substrate ${ }^{7,23,24}$. It would seem there is credibility in the use of bovine teeth in microleakage tests. Several studies have been performed in that way ${ }^{3,19}$. However, the suitability of bovine and swine enamels as substitutes for human enamel in microleakage tests has not yet been proven. The aim of this study was to investigate the microleakage behavior of bovine, swine and human enamels and to establish whether bovine and swine enamels are really an alternative to human teeth in microleakage studies.

\section{MATERIAL AND METHODS}

Sixty freshly extracted bovine incisors, swine molars and human molars were used in the study and were stored in 2\% buffered formalin (Merck, Darmstadt, Germany). All teeth were cleaned and examined for the presence of craze lines, cracks and surface defects that influence dye penetration. The teeth selected were stored in distilled water at $5^{\circ} \mathrm{C}$ to prevent dehydration. Dental blocks were extracted from the crown of the buccal surface (with approximate dimensions of $5 \times 5 \times 5 \mathrm{~mm}^{3}$ ). The enamel blocks were included in a cylinder of polystyrene resin (Cole Farmer Instrument Company, Chicago, USA). Standardized cubic cavities, measuring $2 \times 2 \times 2 \mathrm{~mm}^{3}$, were prepared in the dental blocks. The cavities were prepared with a diamond bur (KG Sorensen, Barueri, SP, Brazil) using constant water spray in a high-speed handpiece (KaVo do Brasil S.A., Joinville, SC, Brazil), coupled to a standard cavity preparation device (manufactured at the university) ${ }^{22}$.

The cavities of the three substrates (bovine, swine and human enamels) were randomly filled in one increment with two commercially available restorative materials: a conventional glass-ionomer cement (Ketac-Fil Plus ${ }^{\circledR}$, 3M ESPE, St. Paul, USA) or a resin composite $\left(Z 100^{\circledR}, 3 \mathrm{M}\right.$ ESPE, St. Paul, USA). The same operator performed all cavity restorations, according to the manufacturer's instructions. For resin composite samples, preparations were lightly dried then etched with 35\% phosphoric acid gel (3M ESPE, St. Paul, MN, USA) for 15 seconds, rinsed for 15 seconds with tap water and blotted with absorbent paper leaving a visibly moist dentin surface. Single Bond ${ }^{\circledR}(3 \mathrm{M}$ ESPE, St. Paul, USA) adhesive system was applied and reapplied with a brush (Southern Dental Industries Limited, Bayswater, Australia), gently dried for 5 seconds and light cured for 20 seconds. Each restoration was light cured for 40 seconds. A visible-light-curing unit (3M Curing Light XL $1500^{\circledR}, 3 \mathrm{M}$, St. Paul, USA) was used, at continuous intensity of $460 \mathrm{~mW} / \mathrm{cm}^{2}$.

All samples were stored in distilled water at $37^{\circ} \mathrm{C} \pm 1^{\circ} \mathrm{C}$ for 24 hours. The restorations were wet finished with a graded series of aluminum oxide disks (Sof-Lex ${ }^{\circledR}, 3 \mathrm{M}$, St. Paul, USA) and stored for 24 hours in distilled water at $37^{\circ} \mathrm{C} \pm 1^{\circ} \mathrm{C}$ before thermocycling.

Then, the samples were thermocycled (FOPUNICAMP, Piracicaba, SP, Brazil) for 1,000 cycles $\left(5 \pm 2{ }^{\circ} \mathrm{C}-55 \pm 2^{\circ} \mathrm{C}\right)$ with a dwell time of 1 minute at each temperature. Afterwards, the interface between the block and the epoxy resin of all specimens was protected with cianoacrylate adhesive Super Bonder (Henkel Loctite Adhesives Ltda., Itapevi, SP, Brazil) up to $1 \mathrm{~mm}$ before reaching the interface tooth/restorative material. The intention was to limit dye penetration to the interface tooth/restorative material only. The blocks were immersed in 2\% methylene blue solution (Merck, Darmstadt, Germany) for 12 hours at $37^{\circ} \mathrm{C}$. After this time, the specimens were rinsed in tap water and dried. The restorations were polished under water cooling with a 1,200-grit $\mathrm{SiC}$ sandpaper (3M ESPE, St. Paul, USA) to remove the surface dye layer, to an average thickness of 0.04-0.05 mm, measured with a digital caliper (Mitutoyo Co., To- 
Abuabara A, Santos AJS, Aguiar FHB, Lovadino JR. Evaluation of microleakage in human, bovine and swine enamels. Braz Oral Res 2004;18(4):312-6.

kyo, Japan). The dental blocks were removed from the resin cylinders and prepared for the spectrophotometric analysis according to the methodology described by Aguiar et al. ${ }^{1}$ (2002).

Results were statistically analyzed at 0.01 level of significance by two-way ANOVA (SAS Institute, Cary, NC), involving the two main factors (substrate and materials). In addition, the interaction among the factors was tested. The response variable was microleakage expressed in dye concentration values. Tukey's multiple comparisons test was applied to determine the difference among means $(\mathrm{p}=0.01)$.

\section{RESULTS}

The results of the statistical analysis (ANOVA) revealed statistically significant differences in microleakage means, expressed in $\mu \mathrm{g}$ of dye, for the restorative materials and the substrates. The analysis of variance (two-way) revealed a significant difference between the restorative materials $(p<0.01)$ and among the substrates $(\mathrm{p}<0.01)$. There was no significant difference for the interaction restorative material $v s$. substrates. Tukey's test showed that glass-ionomer cement groups had the higher leakage means and were statistically different from resin composite groups (Table 1). Regarding the different substrates, human enamel groups showed the lower leakage means and were statistically different from swine and bovine groups. Swine and bovine groups showed no significant differences between each other (Table 1).

\section{DISCUSSION}

Numerous methods have been used to determine microleakage. Qualitative dye penetration is frequently used ${ }^{6,8,13,28}$. The present study evaluated quantitative microleakage. The dye concentration

TABLE 1 - Means and standard deviations ( \pm SD) of dye concentration for all the substrates and combination material vs. substrate.

\begin{tabular}{l|c|c|c}
\hline \hline \multirow{2}{*}{ Substrates } & \multicolumn{3}{|c}{ Dye concentration: $\mu \mathrm{g} / \mathrm{ml} \pm \mathrm{SD}$} \\
\cline { 2 - 4 } & Glass ionomer & & Composite resin \\
\hline Swine & $0.08542 \pm 0.02745^{\mathrm{a}}$ & $*$ & $0.04934 \pm 0.01593^{\mathrm{a}}$ \\
\hline Bovine & $0.07915 \pm 0.02342^{\mathrm{a}}$ & $*$ & $0.05449 \pm 0.01980^{\mathrm{a}}$ \\
\hline Human & $0.04383 \pm 0.02711^{\mathrm{b}}$ & $*$ & $0.03756 \pm 0.00649^{\mathrm{b}}$ \\
\hline \hline
\end{tabular}

Superscript letters indicate intergroup comparisons. Different superscript letters indicate statistically significant differences among groups. ${ }^{*} \mathrm{p}<0.01$. was determined spectrophotometrically. Therefore, it was possible to determine not only the depth but also the quantity of infiltrated dye (volumetric analysis) at the material/substrate interface, eliminating subjective evaluation. The analysis of the data from this study revealed that microleakage behavior is dependent on enamel origin. The microleakage mean values were greater in swine and bovine enamel than in human enamel. Working with dentin, Retief et al. ${ }^{21}$ (1990) also reported that microleakage in bovine teeth restorations was significantly greater than that in human teeth. Investigating the shear bond strength of Scotchbond 2/Silux in bovine and human dentin, regarding quantitative microleakage, the authors suggested that bovine teeth were not suitable substitutes for human teeth in laboratory evaluation.

In this study, the composite resin presented lower leakage means than the glass-ionomer cement. Materials possess different bonding mechanisms. Gwinnett, Matsui ${ }^{10}$ (1967) and Buonocore et al. (1968) suggested that the formation of "resin tags" was the primary attachment mechanism of resin to phosphoric acid etched enamel. Acid etching removes about $10 \mu \mathrm{m}$ of the enamel surface and creates a porous layer 5 to $50 \mu \mathrm{m}$ deep. When a low-viscosity resin is applied, it flows into the microporosities and channels of this layer and polymerizes to form a micromechanical bond with the enamel. A mechanism of adhesion of glass-ionomer cements to the tooth structure has been proposed, involving the development of ionic crosslinks at the tooth restorative interface ${ }^{30}$. This mechanism of adhesion presents lower values of shear bond strength than composite resin. The relationship between weak links and clinical observations of marginal staining, recurrent caries and loss of retention is unknown. Evidence from this study suggests that lower values of shear bond strength can result in higher leakage means.

Differences among the substrates are reported in the current literature. Mature enamel contains approximately $96 \%$ of mineral per tissue weight ( $85 \%$ per volume); the remainder is composed of organic material and water. The main inorganic constituent of enamel is hydroxyapatite, $\mathrm{Ca}_{10}\left(\mathrm{PO}_{4}\right)_{6}(\mathrm{OH})_{2}$, which tends to incorporate a larger number of trace elements ${ }^{11}$. In relation to trace elements, bovine and human teeth do not possess chemical equivalence. Exclusive and significant chemical elements were found in bovine and human enamels $(\mathrm{Sr}, \mathrm{Zr}, \mathrm{Sn}$ in bovine and $\mathrm{Cu}$ 
Abuabara A, Santos AJS, Aguiar FHB, Lovadino JR. Evaluation of microleakage in human, bovine and swine enamels. Braz Oral Res 2004;18(4):312-6.

and $\mathrm{Pb}$ in human enamel). Elements common to both groups were also detected $(\mathrm{P}, \mathrm{S}, \mathrm{Cl}, \mathrm{K}, \mathrm{Ca}$, $\mathrm{Fe}$ and $\mathrm{Zn})^{14}$. Those elements can be related to the development of carious lesions. The element copper $(\mathrm{Cu})$ in the human enamel could be more related to a larger incidence of caries. On the other hand, the presence of strontium ( $\mathrm{Sr}$ ) can be related to low indexes of decay. Analyzing the enamel of bovine, swine and human teeth, Oliveira et al. ${ }^{18}$ (2001) found statistically similar concentrations of $\mathrm{Cu}$ in human and swine enamels, which were not detected in the bovine enamel. Statistically similar concentrations of Sr were found in bovine and swine enamels, which were not observed in the human enamel. This suggests a different acidresistance behavior regarding the development of caries-like lesions. Theoretically, the results of enamel etching in a restorative procedure could be different among the enamel substrates.

Coradazzi et al. ${ }^{7}$ (1998) reported that the shear bond strength in human enamel did not present statistically significant differences in relation to bovine enamel; however, both presented a significant difference in relation to swine enamel. Nevertheless, Barkmeier, Erickson ${ }^{2}$ (1994) not only found the bond strengths in bovine enamel to be lower than in human enamel, but significantly lower, with bovine enamel bond strengths 35\% below those of human enamel. The critical surface tension was lower in bovine than in human teeth, resulting in slightly lower adhesive strength in both enamel and dentin in bovine teeth ${ }^{4}$. Bovine enamel had larger crystal grains and more lattice defects than human enamel, since bovine teeth develop more rapidly before and after eruption ${ }^{15}$. This would also be another reason for the significantly greater shear bond strength of human enamel and dentin compared to bovine substrates. Oesterle et $a l .{ }^{17}$ (1998) concluded that the enamel bond in bovine teeth is $21 \%$ to $44 \%$ weaker than that in human enamel. This could explain the greater microleakage mean values in bovine enamel, although no correlation is found in adhesion and microleakage tests.

The substrates have shown variations of histological and chemical composition, and of structure and morphology that could allow different behavior of the material/substrate interaction. Reeves et $a l .{ }^{20}$ (1995) investigated the microleakage behavior of three dentin bonding systems using human and bovine studies. The authors stated that bovine teeth could be used in lieu of human teeth for in vitro microleakage studies. However, their results indicate differences in the material rank with change of substrate. When the bonding agents were compared at the incisal margin, the rank order of decreasing leakage was, in human substrate, All-Bond $2>$ Universal Bond $3>$ Scotchbond Multi-Purpose, with statistical differences between All-Bond 2 and Scotchbond Multi-Purpose. In bovine substrate, the rank of leakage was AllBond $2>$ Scotchbond Multi-Purpose > Universal Bond 3, with statistical differences between AllBond 2 and Universal Bond 3. This suggests that the statistical differences found in a substrate cannot be the same as those found in the other. Thus, it can be understood that the materials present different microleakage behaviors. Hypothetically, the difference can occur in tests of similar materials, mainly with dentin adhesive systems that possess direct interaction with the substrate.

\section{CONCLUSION}

The information present in the current literature on swine teeth is extremely scarce. Thus, there are no indications that the use of swine substrate as a substitute for human substrate is satisfactory. Besides, the availability and acquisition of this material are disadvantages if compared to bovine teeth, which are easier to obtain. The data from this study support that microleakage did not differ between bovine and swine enamel, but, in both, it was greater than in human enamel. Thus, the use of bovine and swine enamel as suitable substitutes for human enamel in microleakage laboratory tests should be carefully considered. Further studies are required to confirm the similar behavior of the materials before several laboratory situations are undertaken.

\section{ACKNOWLEDGMENTS}

FAPESP - Process number: 01/07976-6. The authors are indebted to the Department of Pharmacology, Anesthesiology, and Therapeutics, School of Dentistry of Piracicaba, State University of Campinas, for the use of laboratory equipment.

The Ethical Committee in Research, protocol n. 038/2002, at the School of Dentistry of Piracicaba, State University of Campinas, approved this investigation. 
Abuabara A, Santos AJS, Aguiar FHB, Lovadino JR. Evaluation of microleakage in human, bovine and swine enamels. Braz Oral Res 2004;18(4):312-6.

\section{REFERENCES}

1. Aguiar FHB, Santos AJS, Groppo FC, Lovadino JR. Quantitative evaluation of marginal leakage of two resin composite restorations using two filling techniques. Oper Dent 2002;27(5):475-9.

2. Barkmeier WW, Erickson RL. Shear bond strength of composite to enamel and dentin using Scotchbond Multi-Purpose. Am J Dent 1994;7(3):175-9.

3. Brackett WW, Gunnin TD, Johnson WW, Conkin JE. Microleakage of light-cured glass-ionomer restorative materials. Quintessence Int 1995;26(8):583-5.

4. Brown K, Puckett AD, Givan D. Surface free energy of bovine versus human enamel and dentin [abstract 1389]. J Dent Res 1992;71:279.

5. Buonocore MG, Matsui A, Gwinnett AJ. Penetration of resin dental materials into enamel surfaces with reference to bonding. Arch Oral Biol 1968;13(1):61-70.

6. Chan MF, Jones JC. A comparison of four in vitro marginal leakage tests applied to root surface restorations. J Dent 1992;20(5):287-93.

7. Coradazzi JL, Silva CM, Pereira JC, Francischone CJ. Shear bond strength of an adhesive system in human, bovine and swinish teeth. Rev Fac Odontol Bauru 1998;6(4):29-33.

8. Ferrari M, Davidson CL. Sealing capacity of a resin-modified glass-ionomer and resin composite placed in vivo in class 5 restorations. Oper Dent 1996;21(2):69-72.

9. Forssel-Ahlberg K, Brännströn M, Edwall L. The diameter and number of dentinal tubules in rat, cat, dog and monkey. A comparative scanning electron microscopic study. Acta Odontol Scand 1975;33(5):243-50.

10. Gwinnett AJ, Matsui A. A study of enamel adhesives. The physical relationship between enamel and adhesive. Arch Oral Biol 1967;12(12):1615-20.

11. LeGeros RZ. Apatites in biological systems. Prog Cryst Growth Charact 1981;4:1-45.

12. Leicester HM. Biochemistry of the teeth. St. Louis: Mosby; 1949. p. 13-102.

13. Lim CC, Neo J, Yap A. The influence of finishing time on the marginal seal of a resin-modified glass-ionomer and polyacid-modified resin composite. J Oral Rehabil 1999;26(1):48-52.

14. Markarian RA, Oliveira TRCF, Mori M, Added N, Villela MM, Rizzuto MA. Comparação entre elementos químicos do esmalte dentário humano e bovino [resumo I-060]. Pesqui Odontol Bras 2001;15 Supl:29.

15. Moriwaki Y, Kani T, Kozatani T, Tsutsumi S, Shimode $\mathrm{M}$, Yamaga R. The crystallinity change of bovine enamel during maturation. J Dent Mat 1968;9:78-85.
16. Nakamichi I, Iwaku M, Fusayama T. Bovine teeth as possible substitutes in the adhesion test. J Dent Res 1983;62(10):1076-81.

17. Oesterle LJ, Shellhart WC, Belanger GK. The use of bovine enamel on bonding studies. Am J Orthod Dentofacial Orthop 1998;114(5):514-9.

18. Oliveira TRCF, Markarian RA, Mori M, Added N, Villela MM, Rizzuto MA. Cobre e estrôncio no esmalte humano, bovino e suíno hígidos [resumo I-062]. Pesqui Odontol Bras 2001;15 Supl:29.

19. Puckett AD, Fitchie JG, Bennett B, Hembree JH. Microleakage and thermal properties of hybrid ionomer restoratives. Quintessence Int 1995;26(8):577-81.

20. Reeves GW, Fitchie JG, Hembree JH, Puckett AD. Microleakage of new dentin bonding systems using human and bovine teeth. Oper Dent 1995;20(6):230-5.

21. Retief DH, Mandras RS, Russell CM, Denys FR. Extracted human versus bovine teeth in laboratory studies. Am J Dent 1990;3(6):253-8.

22. Santos AJS, Gomide HA, Pedrosa SF, Martins LRM, Soares CJ. Development of a standard cavity preparation appliance [abstract 351]. J Dent Res 2001;80:1043.

23. Saunders WP. The shear impact retentive strengths of four dentin bonding agents to human and bovine dentin. J Dent 1988;16(5):233-8.

24. Schilke R, Bauss O, Lisson JA, Schuckar M, Geurtsen W. Bovine dentin as a substitute for human dentin in shear bond strength measurements. Am J Dent 1999;12(2):926.

25. Sidhu SK. A comparative analysis of techniques of restoring cervical lesions. Quintessence Int 1993;24(8):5539.

26. Suga S, Kondo M, Onodera A, Kubota Y, Ohtsuka M. Electron microprobe analyses on the distributions of $\mathrm{Cl}$, $\mathrm{Mg}$ and $\mathrm{Na}$, in the enamels of various animals. J Oral Biol 1971;13:85-94.

27. Tagami J, Tao L, Pasheley DH, Horner JA. The permeability of dentin from bovine incisors in vitro. Arch Oral Biol 1989;34(10):773-7.

28. Toledano M, Osorio E, Osorio R, Garcia-Godoy F. Microleakage of class $\mathrm{V}$ resin-modified glass ionomer and compomer restorations. J Prosthet Dent 1999;81(5):6105.

29. Weichert CK, Presch W. Elements of chordate anatomy. $4^{\text {th }}$ ed. New York: McGraw-Hill Book Company; 1975.

30. Wilson AD, Prosser HJ, Powis DM. Mechanism of adhesion of polyelectrolyte cements to hydroxyapatite. J Dent Res 1983;62:590-2. 